\title{
FISHES FROM THE PRIVATE NATURAL HERITAGE RESERVE PACATUBA FARM AND ITS SURROUNDING AREAS, PARAÍBA STATE, NORTHEASTERN BRAZIL
}

\author{
PEIXES DA RESERVA PARTICULAR DO PATRIMÔNIO NATURAL \\ FAZENDA PACATUBA E SEUS ARREDORES, ESTADO DA PARAÍBA, NORDESTE DO BRASIL
}

Shaka Nóbrega Marinho Furtado Gitá Juan Soterorudá Brito² Kassiano dos Santos Sousa ${ }^{3}$ Telton Anselmo Ramos

\section{Resumo}

A Reserva Particular do Patrimônio Natural Fazenda Pacatuba está localizada na porção baixa da bacia do rio Paraíba do Norte, um dos últimos remanescentes de Mata Atlântica no norte do rio São Francisco. Juntamente com a floresta de Jacuípe e a Reserva Biológica de Guaribas, é considerada uma área de importância biológica ainda desconhecida e prioritária para a conservação da biodiversidade no Nordeste. Assim, o presente estudo teve como objetivo analisar a ictiofauna da reserva e seu entorno, a fim de contribuir para os dados sobre a distribuição das espécies de peixes da Mata Atlântica do Nordeste e para o conhecimento de sua biodiversidade. Foram coletados 1.005 exemplares em cinco pontos amostrais, distribuídos em 6 ordens, 11 famílias, 16 gêneros e 21 espécies de peixes de água doce.

Palavras-chave: Peixes, Mata Atlantica, Riachos, Conservação.

\begin{abstract}
The Private Natural Heritage Reserve Pacatuba Farm is located in the Paraíba do Norte river low basin, one of the last remnants of Atlantic Forest in the north of the São Francisco river. Together with Jacuípe forest and Guaribas Biological Reserve, it is considered an area of biological importance still unknown and priority for the biodiversity conservation in the Northeast. Thus, the present study aimed to analyze the icthyofauna from the reserve and its surroundings in order to contribute to the data on the fish species distribution in the Northeastern Atlantic Forest and to the knowledge of its biodiversity. It was collected a total of 1.005 specimens at five sampling sites, which are distributed over 6 orders, 11 families, 16 genera and 21 species of freshwater fish.
\end{abstract}

\footnotetext{
1 Programa de Pós-graduação em Ciências Biológicas, Universidade Federal da Paraíba, Campus I, João Pessoa, PB. BRASIL. CEP: 58059-900.

2 Programa de Pós-graduação em Ciências Biológicas, Universidade Federal da Paraíba, Campus I, João Pessoa, PB. BRASIL. CEP: 58059-900.

3 Programa de Pós-graduação em Ciências Biológicas, Universidade Federal da Paraíba, Campus I, João Pessoa, PB. BRASIL. CEP: 58059-900.

4 Universidade Estadual da Paraíba, Departamento de Biologia/CCBS, Laboratório de Ecologia Aquática, Campus universitário, CEP 58109-753, Campina Grande, PB, Brasil.
} 
Keywords: Fish, Atlantic Forest, Streams, Conservation.

\section{INTRODUCTION}

The Neotropical freshwater fish fauna is considered the richest in the world (Albert and Reis 2011). Rosa and Menezes (1996) estimated that the number of neotropical fish species of continental ecosystems to be around 5.000 species. However, Reis et al. (2003) cataloged a total of 6.025 fish species to the Neotropics. Considering this zoogeographical region, the South America has the most diverse fish fauna. However, the understanding and appreciation of this rich fauna are negatively affected by the still incomplete knowledge about its biology, taxonomy and systematics (Menezes 1996; Ramos et al. 2014).

According to Buckup et al. (2007), Brazil embraces the greatest diversity of freshwater fish, possessing approximately $\mathbf{2 . 5 0 0}$ endemic species. Furthermore, this study reveals that the number of fish species described in Brazil has significantly increased in recent years with more than $20 \%$ annual growth due to the expansion of sampling mainly in the headwaters of some Brazilian sites (Buckup et al. 2007). Nevertheless, there is still a large gap about the real diversity of this fauna (Gonçalves and Braga 2013).

Most river basins of the Brazilian Northeast states (Alagoas, Ceará, Paraíba, Pernambuco, part of the Piauí and Rio Grande do Norte territory) belongs to the Northeast Middle-East ecoregion, comprising the river basins located at the east of the Parnaíba river (Maranhão-Piauí ecoregion) and north of the San Francisco river (the San Francisco ecoregion) (Rosa et al. 2003; Abell et al. 2008; Albert et al. 2011).

Some studies claim the data about the Brazilian fish diversity is concentrated in a few regions so that little is known about the diversity and taxonomy of freshwater fish from the Northeast. Therefore, diversity estimates can be considered incipient, especially regarding to the existence of a few representative collections of freshwater fish in this region (Rosa and Menezes 1996; Menezes 1996; Langeani et al. 2009; Ramos et al. 2014).

The State of Paraíba has rivers draining its waters over the eastern portion of the Brazilian shield, where the Borborema plateau is the main watershed, directing the rivers west to east up to the Atlantic Ocean (Rosa et al. 2003). The state river system consists of medium-sized basins, such as the Paraíba do Norte and Piranhas rivers, and small basins, such as coastal basins of Curimataú, Camaratuba, Mamanguape, Miriri, Gramame and Abiaí rivers (AESA 2013).

In this study we surveyed the icthyofauna from the Private Natural Heritage Reserve (in portuguese: Reserva Particular do Patrimônio Natural - RPPN; category for private reserves in the Brazilian system of protected areas) Pacatuba Farm and its surroundings, in order to contribute to the data on the distribution of fish species in the Atlantic Forest. from the Northeast. The RPPN Pacatuba Farm is one of the 
remaining fragments of Atlantic Forest in the State of Paraíba (Silvestre and Xavier 2013) which is characterized by its great biodiversity and high levels of endemism (Myers et al. 200o). Therefore, the data collection about the fish fauna of this biome could contribute in the understanding of its biodiversity, as well as in planning strategies for conservation.

\section{MATERIAL AND METHODS}

\section{Study area}

The survey of fish populations was developed at RPPN Pacatuba Farm and its surroundings (Figure 1), municipality of Sapé ( $7^{\circ} 05^{\prime} 47^{\text {"S }}$ and $\left.35^{\circ} 13^{\prime} 58^{\prime \prime} \mathrm{W}\right)$, state of Paraiba, Brazil. The RPPN is administered by the Japungú Company and comprises an area of 266.53 hectares, in the Atlantic Forest (Silvestre and Xavier 2013) and the Paraiba do Norte river basin (AESA 2013). Located at the Paraiba Forest Mesoregion, with altitude between 75 and 150 meters and an average rainfall of $1600 \mathrm{~mm}$. The vegetation is predominantly formed by semideciduous seasonal forest (IBGE 1992; Pereira et al. 2012; Silvestre and Xavier 2013).

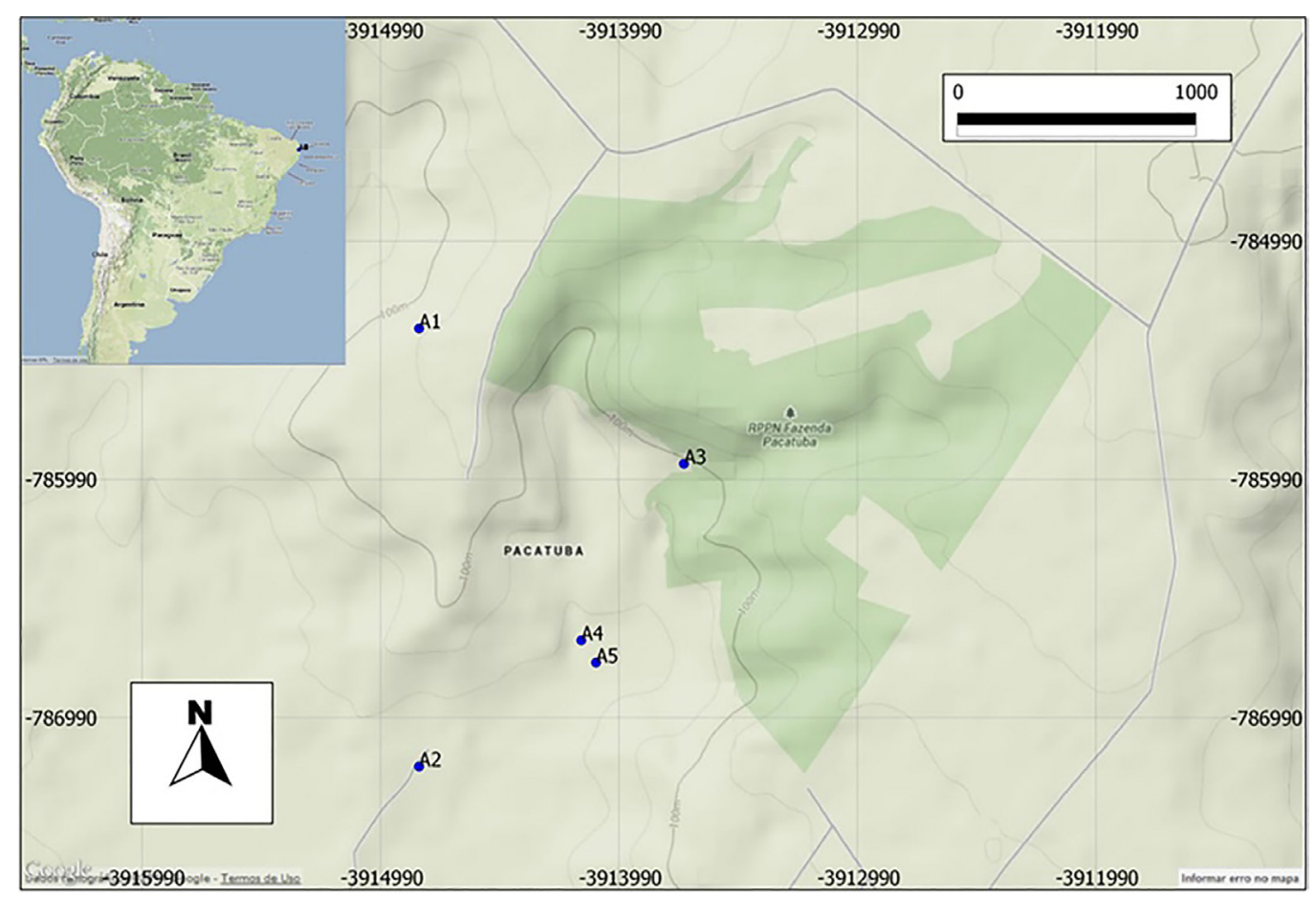

Figure 1. Map of the Private Natural Heritage Pacatuba Farm, municipality of Sapé-PB, Brazil. Sampling sites highlighted. 
Together with the Jacuípe forest and the Guaribas Biological Reserve, the Pacatuba Farm is considered an area of biological importance with knowledge still insufficient but a priority for the biodiversity conservation in the Northeastern of Brazil (Conservation International et al. 1993, MMA 2003).

\section{Data collect}

The fish species were collected in water bodies arranged along the reserve and its surroundings. The expedition for collection of freshwater fish was held from $17^{\text {th }}$ to 21st November, 2013 at five sample sites within the RPPN Pacatuba Farm (Table 1, Figure 2). The sampling sites were selected according to their availability of water bodies.

Table 1. Geographic coordinates and location of the five sampling sites in RPPN Pacatuba Farm, Paraiba do Norte river basin, Paraíba, Brazil.

\begin{tabular}{|c|c|c|}
\hline Sampling sites & Geographic coordinates & Locality \\
\hline A1 & $\mathrm{o}^{\circ} \mathrm{O} 02^{\prime} 14^{\prime \prime} \mathrm{S} 35^{\circ}$ 10' 03” W & Downstream of Dam Pacatuba \\
\hline $\mathrm{A}_{2}$ & $07^{\circ} 03^{\prime} 13^{\prime \prime} \mathrm{S} 35^{\circ} 10^{\prime} 03^{\prime \prime} \mathrm{W}$ & Stream tributary of São Salvador I \\
\hline $\mathrm{A}_{3}$ & $07^{\circ} 04^{\prime} 22^{\prime \prime} \mathrm{S} 35^{\circ} 16^{\prime} 15^{\prime \prime} \mathrm{W}$ & Stream tributary of São Salvador II \\
\hline $\mathrm{A}_{4}$ & $07^{\circ} 02^{\prime} 56^{\prime \prime} \mathrm{S} 35^{\circ} 09^{\prime} 41^{\prime \prime} \mathrm{W}$ & Poço dos Cavalos \\
\hline $\mathrm{A}_{5}$ & $\mathrm{o}^{\circ} 02^{\prime} 59^{\prime \prime} \mathrm{S} 35^{\circ}$ o9' $39^{\prime \prime} \mathrm{W}$ & Stream tributary of São Salvador III \\
\hline
\end{tabular}



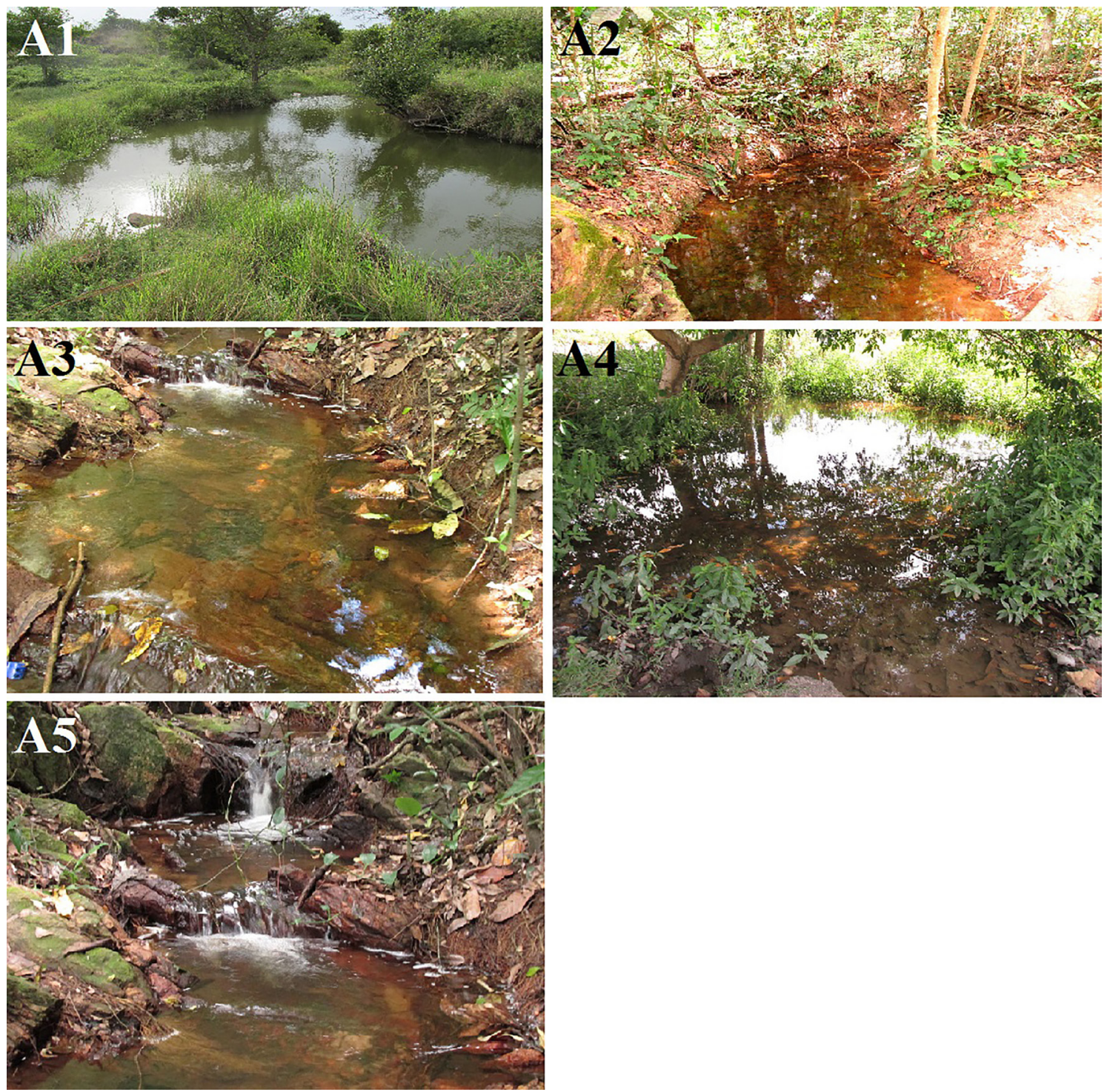

Figure 2. Sampling sites (A1-A5, see Table 1) Private Natural Heritage Pacatuba Farm, municipality of Sapé-PB, Brazil.

The collections of specimens was carried out in October using seines $(4 \mathrm{~m}$ long, $2 \mathrm{~m}$ height, mesh size $5 \mathrm{~mm}$ ), castnets ( $2 \mathrm{~m}$ height, mesh size $15 \mathrm{~mm}$ ), gillnets of various mesh sizes $(15,25,35,45$ and $55 \mathrm{~mm}$ ), and dip nets (mesh size 5 and $10 \mathrm{~mm}$ ), according to environmental and hydrological conditions of each sampling site. The ichthyological materials obtained in the samples were fixed in the field into a $10 \%$ formalin solution neutralized with tetraborate and sodium and posteriorly preserved in 70\% ethanol and deposited at Ichthyological Collection at Universidade Federal da Paraíba (UFPB). The specimens were treated according to Malabarba and Reis (1987) and were identified to the lowest taxa whenever possible at the Laboratório de Sistemática e Morfologia de Peixes (UFPB) using specialized literature for the group (Britskiet et al. 1984, 2007; Kullander 1988; Menezes et al. 2007; Ploeg 1991). The taxonomic classification followed Eschmeyer (2016). The collection was deposited in 
the Ichthyological Collection of the Departamento de Sistemática e Ecologia at the same university.

\section{Data analysis}

The sampling efficiency was evaluated by species diversity or collector accumulation curves. Jackknife 1 was used as statistical estimators for calculate the species richness. This test estimates the total richness by adding the richness observed (the number of collected species) to a parameter calculated from the number of rare species and the number of samples (Santos 2006). The data sample efficiency and others estimators were obtained using the software EstimateS V.9.1 (Coldwell 2013) to obtain abundance, species richness, the Shannon Diversity index and species evenness was used the software Primer 6 Beta (Clarke and Gorley 2006).

\section{RESULTS AND DISCUSSION}

A total of 1.005 fish specimens were collected at the five sampling sites. These specimens were identified into 6 orders, 11 families, 16 genera and 21 species of freshwater fish (Table 2). Some species in the Figure 3. The family Characidae was the most representative, with eight species, followed by Erythrinidae, Poeciliidae and Cichlidae, with two species each. The other families had only one species.

Table 2. Freshwater fish species list recorded in the Private Natural Heritage Pacatuba Farm in each sampled site, and their respective relative abundances.

\begin{tabular}{|c|c|c|c|c|c|c|c|}
\hline ORDER/ Family/ Species & A1 & A2 & A3 & $\mathbf{A}_{4}$ & A5 & Total & $\begin{array}{c}\text { Voucher } \\
\text { UFPB }\end{array}$ \\
\hline \multicolumn{8}{|l|}{ CHARACIFORMES } \\
\hline \multicolumn{8}{|l|}{ Curimatidae } \\
\hline $\begin{array}{l}\text { Steindachnerina notonota (Miranda Ribeiro, } \\
\text { 1937) }\end{array}$ & 0.00 & 0.00 & 0.00 & 0.00 & 0.28 & 0.10 & 11206 \\
\hline \multicolumn{8}{|l|}{ Crenuchidae } \\
\hline Characidium bimaculatum Fowler, 1941 & 0.24 & 0.00 & 0.00 & 0.00 & 7.73 & 2.89 & 11197 \\
\hline \multicolumn{8}{|l|}{ Characidae } \\
\hline Astyanax bimaculatus (Linnaeus, 1758) & 3.09 & 1.27 & 0.00 & 0.00 & 1.38 & 1.99 & 11280 \\
\hline Astyanax fasciatus (Cuvier, 1819) & 15.68 & 22.78 & 0.00 & 0.00 & 0.55 & 10.35 & 11285 \\
\hline Compsura heterura Eigenmann, 1915 & 15.44 & o.oo & 0.00 & 50.00 & 27.90 & 16.62 & 11281 \\
\hline Hemigrammus marginatus Ellis, 1911 & 6.89 & 5.70 & 0.00 & 50.00 & 37.85 & $17 \cdot 51$ & 11202 \\
\hline
\end{tabular}




\begin{tabular}{|c|c|c|c|c|c|c|c|}
\hline ORDER/ Family/ Species & A1 & A2 & A3 & $\mathrm{A}_{4}$ & A5 & Total & $\begin{array}{l}\text { Voucher } \\
\text { UFPB }\end{array}$ \\
\hline Hemigrammus unilineatus (Gill, 1858) & 0.00 & 0.00 & 69.35 & 0.00 & 0.00 & 4.28 & 11245 \\
\hline Cheirodon jaguaribensis Fowler, 1941 & 9.03 & 5.70 & 0.00 & 0.00 & $3 \cdot 31$ & 5.87 & 11278 \\
\hline Serrapinnus heterodon (Eigenmann, 1915) & 17.81 & 22.15 & 0.00 & 0.00 & 0.00 & 10.95 & 11277 \\
\hline Serrapinnus piaba (Lütken, 1875) & 12.59 & 7.59 & 0.00 & 0.00 & 2.49 & $7 \cdot 36$ & 11219 \\
\hline \multicolumn{8}{|l|}{ Erythrinidae } \\
\hline $\begin{array}{l}\text { Erythrinus erythrinus (Bloch \& Schneider, } \\
\text { 1801) }\end{array}$ & 0.24 & 0.00 & 4.84 & 0.00 & 0.00 & 0.40 & 11213 \\
\hline Hoplias malabaricus (Bloch, 1794) & 0.71 & 0.00 & 3.23 & 0.00 & 0.00 & 0.50 & 11248 \\
\hline \multicolumn{8}{|l|}{ SILURIFORMES } \\
\hline \multicolumn{8}{|l|}{ Callichthyidae } \\
\hline Megalechis thoracata (Valenciennes, 1840 ) & 0.00 & 0.00 & 1.61 & 0.00 & 0.00 & 0.10 & 11246 \\
\hline \multicolumn{8}{|l|}{ Loricariidae } \\
\hline Hypostomus pusarum (Starks, 1913) & 0.71 & 0.00 & 0.00 & 0.00 & 0.00 & 0.30 & 11241 \\
\hline \multicolumn{8}{|l|}{ Heptapteridae } \\
\hline Rhamdia quelen (Quoy \& Gaimard, 1824) & 0.24 & 0.00 & 0.00 & 0.00 & 0.00 & 0.10 & 11240 \\
\hline \multicolumn{8}{|l|}{ GYMNOTIFORMES } \\
\hline \multicolumn{8}{|l|}{ Gymnotidae } \\
\hline Gymnotus carapo Linnaeus, 1758 & 0.00 & 0.00 & 1.61 & 0.00 & 0.00 & 0.10 & 11273 \\
\hline \multicolumn{8}{|l|}{ CYPRINODONTIFORMES } \\
\hline \multicolumn{8}{|l|}{ Poeciliidae } \\
\hline Poecilia reticulata Peters, 1859 & 2.61 & 2.53 & 16.13 & 0.00 & 1.38 & 2.99 & 11224 \\
\hline Poecilia vivipara Bloch \& Schneider, 1801 & 14.01 & 31.65 & 0.00 & 0.00 & 16.57 & 16.82 & 11226 \\
\hline \multicolumn{8}{|l|}{ SYNBRANCHIFORMES } \\
\hline \multicolumn{8}{|l|}{ Synbranchidae } \\
\hline Synbranchus sp. & 0.00 & 0.00 & 1.61 & 0.00 & 0.00 & 0.10 & \\
\hline \multicolumn{8}{|l|}{ CICHLIFORMES } \\
\hline \multicolumn{8}{|l|}{ Cichlidae } \\
\hline Cichlasoma orientale Kullander, 1983 & 0.48 & 0.00 & 0.00 & 0.00 & 0.55 & 0.40 & 11201 \\
\hline Crenicichla menezesi Ploeg, 1991 & 0.24 & 0.63 & 1.61 & 0.00 & 0.00 & 0.30 & 11225 \\
\hline
\end{tabular}





Figure 3. Some fish species of Private Natural Heritage Pacatuba Farm. A. Characidium bimaculatum, B. Hemigrammus marginatus, C. Hemigrammus unilineatus, D. Serrapinnus piaba, E. Erytrinus erytrinus, F. Crenicichla menezesi, G. Hypostomus pusarum, H. Megalechis thoracata.

The abundance and proportional variety of Characidae was expected, once the biodiversity and richness patterns of this family are characteristic for all brazilian regions (Rosa et al. 2003; Buckup et al. 2007; Ramos et al. 2014). In the Neotropical region (Reis et al. 2003) this family is the largest and the most complex among 
tropical fresh water fish (Britski et al. 1999; Nelson 2006) especially due to adaptative plasticity, body shape and feeding strategies. A high abundance of Characidae at the sampled sites was also expected, once some aspects of this group allow the occupancy of a large number of habitats (Lowe-McConnell 1999; Graça and Pavanelli 2007), and the shoaling formation contributes to capture a larger number of specimens (Ramos 2012).

The abundance of Erythrinidae, Poeciliidae and Cichlidae families was expected, because these groups are widely distributed in brazilian intercontinental waters, registered in others lists for different localities of the country (Bichuette and Trajano 2003; Oyakawa 2003; Pompey and Godinho 2003; Rosa et al. 2003; Ramos et al. 2005; Granado-Lorencio et al. 2007; Leal et al. 2009; Sarmento-Soares and Martins-Pinheiro 2009; Ramos et al. 2014).

The species with the highest abundance were Hemigrammus marginatus Ellis, with 176 specimens collected (corresponding to $18 \%$ of the sample), followed by Poecilia vivipara Bloch and Schneider (17\%), Compsura heterura Eigenmann (17\%), Serrapinnus heterodon Eigenmann (11\%) and Astyanax aff. fasciatus Cuvier (10\%) (Figure 4). Hemmigrammus marginatus, C. heterura, S. heterodon and $A$. fasciatus belong to a group popularly known in the region as "piabas" and not arouse greater interest from the local population. These fishes are only used by fishermen as bait to catch larger fish. Poecilia vivipara popularly known as "guarú", "guru" or "barrigudinho" is a kind of small fish that also does not arouses interest from the local population. Therefore, none of these abundant species have commercial importance in the region. Poecilia is a prolific genus with viviparous reproduction, which contributes significantly to its population increase (Ramos 2012).

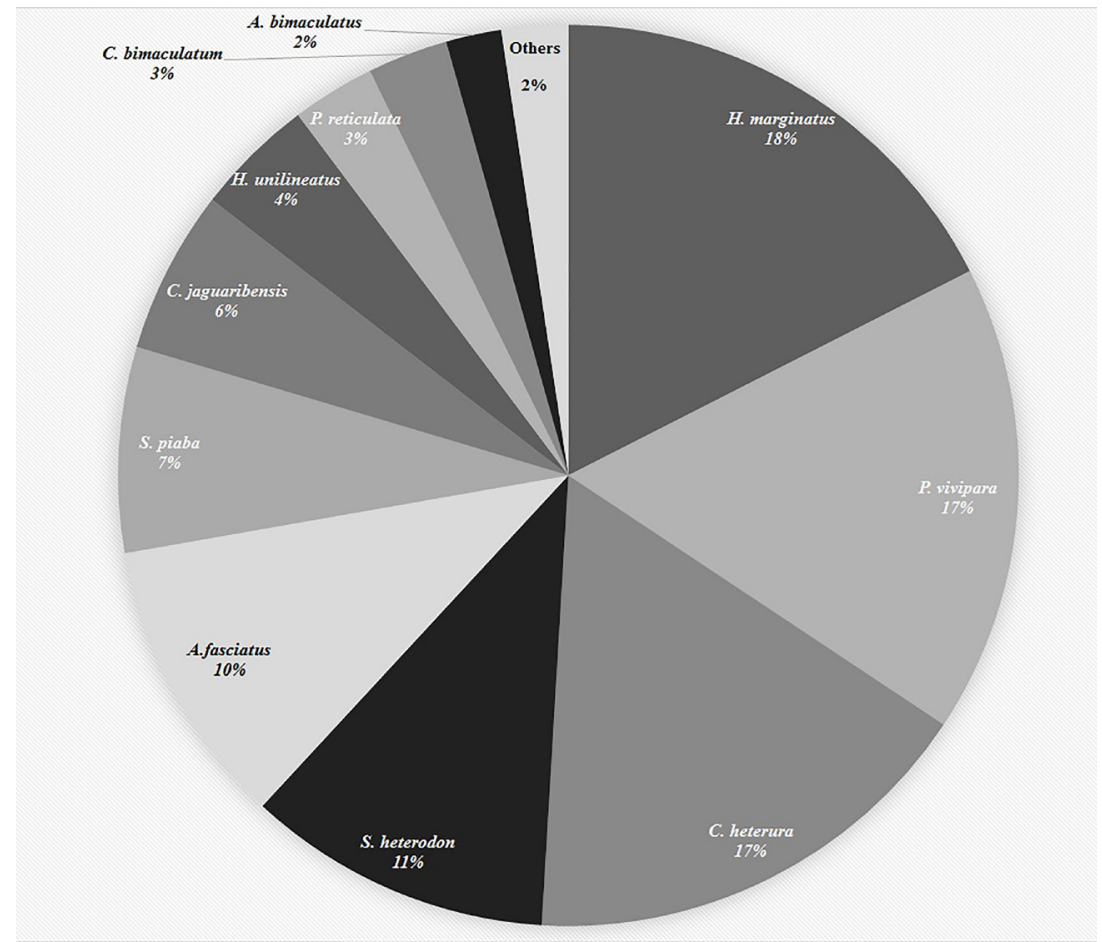

Figure 4. Graphic showing the species represented by more than 40 specimens. 
According to Sparre and Venema (1997), populations of Hemigrammus marginatus (the most abundant species) showed two peaks of abundance during the period of year, suggesting more than one reproductive event in a twelve-month cycle. In this context, $H$. marginatus population has its greatest input of individuals in the dry season and the lowest in the rainy season (Lawrence et al. 2012). The high abundance of this species in the community described here would be explained due to a species recruitment event, once the collection period coincided with the peak months of its population according to Lourenço et al. (2012).

Hemigrammus marginatus and Poecilia reticulata were the most common species being sampled in four out of five collection points. Astyanax bimaculatus, Astyanax fasciatus, Cheirodon jaguaribensis, Compsura heterura, Serrapinnus piaba, Poecilia vivipara and Crenicichla menezesi occurred at three sites each $(60 \%$ of the sites), followed by Characidium bimaculatum, Serrapinnus heterodon, Erythrinus erythrinus, Hoplias malabaricus and Cichlasoma orientale in two sites (40\% of the sites) (Table 2). The other seven species occurred in a single sampling site.

The Characiformes was the most representative considering all sampled points, with $57 \%$ of all individuals captured belong to this order and distributed in 12 taxa. The Characiformes species are distributed in 4 families and 8 genera. The second most representative order was the Siluriformes, with three species in three genera and three families, representing $14 \%$ of the species. Some species of the Siluriformes are characterized by inhabiting water environments with high turbidity, as in these waters there is a higher occurrence of fish species with secondary structures adapted to chemical perception of the environment, as the barbels of many species of the order (Melo et al. 2005; Kavalco and Pazza 2007).

In this survey no endemic species of the Atlantic Forest or the Paraíba do Norte river basin were collected. Also, it was not registered any rare or endangered species according to the National Red List of Fauna Species - Fish and Aquatic Invertebrate (MMA 2014) and IUCN lists (2016). Hemigrammus unilineatus has the Amazon region as type locality, and currently has being recorded in some Northeast rivers from Alagoas and Paraiba states). The occurrence of this species is considered by researchers as natural, not introduced, based on preterit relations between the Atlantic and Amazon Forests (Menezes et al. 2007). Poecilia reticulata was the only exotic species recorded in the study, founded in four of the five collection sites. According to Ramos (2012), this is a small fish, which is currently widely distributed in brazilian northeast and is widely used in aquarisms and as control of infectioncarrying insects.

Considering the total of species and richness found in each collection site, the A1 point had the highest abundance of species, and represents the richest area in terms of diversity (Table 3). On the other hand, the A4 point showed the lowest abundance of species. 
Table 3. Diversity data of sampled areas. (S) Total species; (N) Total individuals; (d) Species richness; $\left(\mathrm{J}^{\prime}\right)$ Evenness index; ( $\left.\mathrm{H}^{\prime}\right)$ Shannon index.

\begin{tabular}{cccccc}
\hline Locality & S & N & d & J' & H'(loge) \\
\hline $\mathrm{A}_{1}$ & 16 & 421 & 2.482 & 0.7862 & 2.18 \\
$\mathrm{~A}_{2}$ & 9 & 158 & 1.58 & 0.7908 & 1.738 \\
$\mathrm{~A}_{3}$ & 8 & 62 & 1.696 & 0.5154 & 1.072 \\
$\mathrm{~A}_{4}$ & 2 & 2 & 1.443 & 1 & 0.6931 \\
$\mathrm{~A}_{5}$ & 11 & 362 & 1.697 & 0.6741 & 1.617 \\
\hline
\end{tabular}

According to the accumulation curve, based on a non-parametric method, the number of species recorded in this study did not show a tendency to stabilize, thus, the richness estimated is higher (Jackknife $1=26.6$ species) than the one observed (21 species) (Figure 5). However, this was the first sample in an important priority area for biodiversity conservation in northeast of Brazil. The action developed in this study proved to be effective. This statement can be supported when we compare the number of species of freshwater fish (21) listed in this survey with those of coastal basins in the Atlantic Forest domain as the Gramame river with 22 species (Torelli et al. 1997; Gomes-Filho and Rosa 2001), watershed of the Jaguaribe river with 17 species (Ricardo Rosa, personal communication), both basins in the state of Paraiba. When compared with rainforest areas, considered remnants of Atlantic Forest in the Caatinga, were recorded 27 species of freshwater fish (Rosa and Groth 2004). In the Pratagi river basin (Rio Grande do Norte), Paiva et al. (2014) found 22 species of which 13 are from freshwater. However, it is important to note that although they showed a higher richness as result, they performed the study in an area with greater extension than the one used in our survey. Thus, the fish diversity recorded in the Pacatuba Farm can be relatively similar to that found in other water bodies under the influence of the Atlantic Forest from the Oriental Middle-Northeast ecoregion.

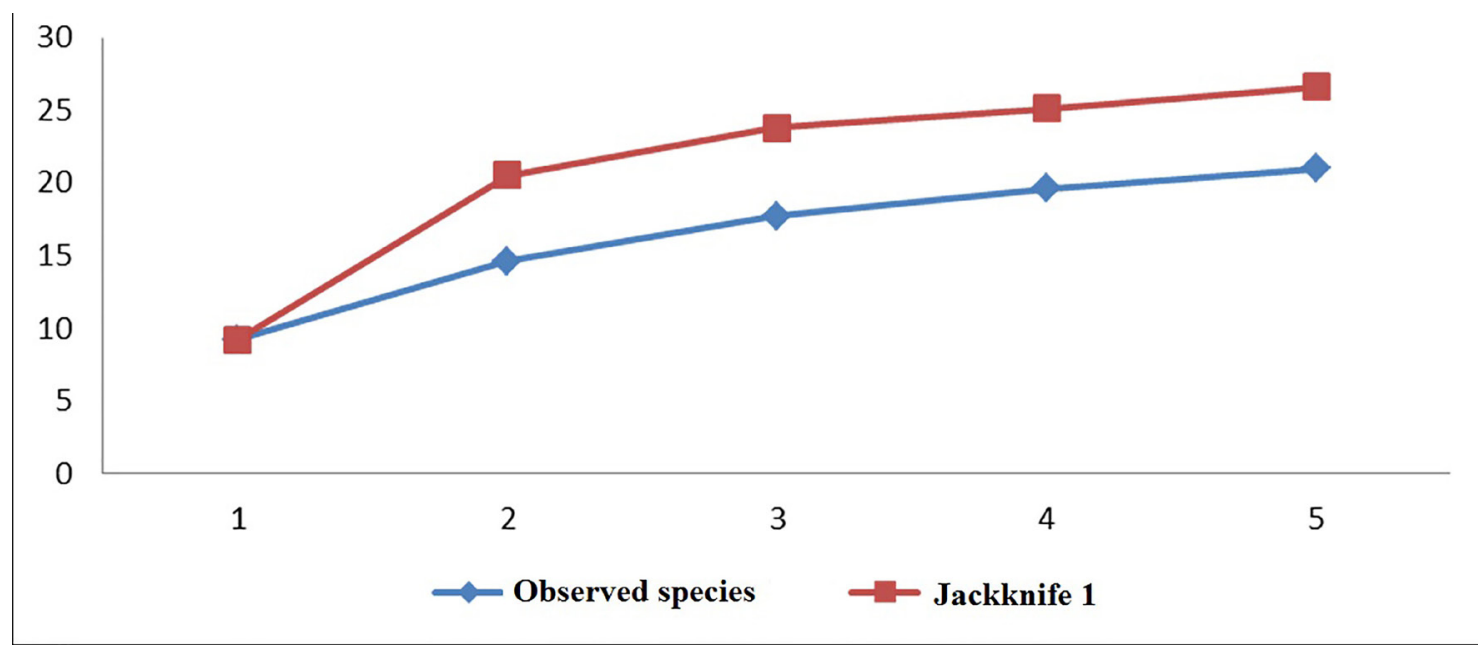

Figure 5. Rarefaction curve of the richness estimator for the Private Natural Heritage Pacatuba Farm - PB. 
The basin of the Paraíba do Norte river exhibit nearly 44 species of freshwater fish (fish data collection from the UFPB, the most representative of northeast of Brazil), so the 21 species recorded in the Pacatuba Farm and in its surroundings, approximadely $50 \%$ of the freshwater ichtyofauna of the basin, is represented in this region. These dada leads us to emphasize the importance of the RPPN Pacatuba Farm for the diversity of northeastern fish.

\section{Taxonomic identity of the observed specimens}

\section{Steindachnerina notonota (Miranda Ribeiro, 1937)}

Material examined. Table 2.

This species have relatively elogated body, head with a mouth subterminal, mandible, maxilla and premaxilla without teeth. Lateral line with 31-24 perforated scales, 5 series of scales above the lateral line. Fins: $i+9$ dorsal rays; $i+12-13$ pectoral rays; $i+8$ pelvic rays; $i 1+7-8$ anal rays. The body have an silvery-yellow pattern of color with the dorsal region darkest than the ventral portion. The fins are yellow colored and the dorsal fin presents a black spot in the base of the median rays. This species is endemic of northeastern Brazil.

\section{Characidium bimaculatum Fowler, 1941}

Material examined. Table 2; Figure 3A.

Elongated body; head with a mouth terminal, small teeth arranged in the mandible and premaxilla, the upper maxilla have no teeth. Lateral line complete with 32-35 perforated scales. Fins: ii-8-9 dorsal rays; $i i i+8-9$ pectoral rays; $i+8$ pelvic rays; $i i i+5-6$ anal rays. The body have a yellowish-white pattern of color with a dark band along the lateral line associated to a spot similar to the humeral spot and an ellipsoid elongate in the caudal peduncle. This species was considered endemic of the Middle Eastern Northeast ( Rosa et al. 2003), but it was also founded at the Parnaiba river (Ramos et al. 2014) and the São Francisco basins (Melo and Espíndola 2016).

\section{Astyanax bimaculatus (Linnaeus, 1758)}

Material examined. Table 2.

The species of the genus Astyanax distinguished from its congeners by the presence of a lateral line complete and a premaxilla with a 2 rows of teeth. The mainly difference from Astyanax fasciatus is that A. bimaculatus have a conspicuous horizontally-ovate humeral spot. A. bimaculatus present a deep body; head with a mouth terminal; premaxilla with two rows of teeth. The lateral line is a slightly curved in the anterior portion with 35-37 perforated scales. Fins: ii-9 dorsal rays; i+11-12 pectoral rays; i+7 pelvic rays; iii-21-25 anal rays. The body have a yellowish-white pattern of color with a dark horizontally-ovate humeral spot and another spot on the caudal peduncle; reddish-yellow fins. 


\section{Astyanax fasciatus (Cuvier, 1819)}

Material examined. Table 2.

The species of the genus Astyanax distinguished from its congeners by the presence of a lateral line complete and a premaxilla with a 2 rows of teeth. A. fasciatus present a deep body; head with a mouth terminal. The lateral line is a slightly curved in the anterior portion with 34-37 perforated scales. Fins: ii+9 dorsal rays; i+12-13 pectoral rays; $i+7$ pelvic rays; $i i+24-26$ anal rays. Body tiwh an silvery pattern of color with the dorsal portion darkest than the ventral; hyaline fins; a dark band from the center of caudal fin along all its extent. Differ from $A$. bimaculatus by the inconspicuous and vertically humeral spots.

\section{Compsura heterura Eigenmann, 1915}

Material examined. Table 2.

This species is member of subfamily Cheirodotinae and presents a premaxilla with only one row of teeth, a mandible and a pseudotympanum evident. Compsura heterura have a deep body; head with a mouth terminal. Lateral line incomplete with 10-13 perforated scales. Fins: $i i+9$ dorsal rays; $i+9-10$ pectoral rays; $i+7$ pelvic rays; ii-iii+15-18 anal rays. Body silvery-white; black spot on the caudal penduncle; reddishyellow fins. Differs from the other species of family Characidae by the presence of modified scales in the base of caudal fin.

\section{Hemigrammus marginatus Ellis, 1911}

Material examined. Table 2; Figure $3 \mathrm{~B}$.

The species of the genus Hemigrammus differs from the others characids by the presence of a lateral line incomplete and scales covering at least part of caudal-fin lobes. H. marginatus have a deep body; head with a mouth terminal, premaxilla with 2 rows of teeth. Lateral line with 9-11 perforated scales. Fins: ii+9 dorsal rays; $i+10-12$ pectoral rays; $i+7$ pelvic rays; $i i i+17-22$ anal rays. Body silvery-white with a rhombic spot in the caudal peduncle; dark distal margin of caudal fin. Differs from $H$. unilineatus and $C$. jaguaribensis by the darkest distal margin of caudal fin, hyalines dorsal and anal fins with no dark spots.

\section{Hemigrammus unilineatus (Gill, 1858)}

Material examined. Table 2; Figure $3 \mathrm{C}$.

Deep body; head with a mouth terminal, premaxilla with 2 rows of teeth. Lateral line incomplete with 10 to 12 perforated scales. Fins: ii+9 dorsal rays; i+10-12 pectoral rays; i+7 pelvic rays; iii-v+22-24 anal rays. Orange body, dorsal and anal fins with orange, black and white bands, orange caudal fin. These spots are external morphological caracteres that distinguish Hemigrammus unilineatus from $H$. marginatus and Cheirodon jaguaribensis. 


\section{Cheirodon jaguaribensis Fowler, 1941}

Material examined. Table 2.

Deep body; head with a mouth terminal, premaxilla with 2 rows of teeth. Lateral line incomplete with 9-12 perforated scales. Fins: ii+8-9 dorsal rays; i+9-12 pectoral rays; $\mathrm{i}+6-7$ pelvic rays; $\mathrm{ii}+\mathbf{2 2 - 2 5}$ anal rays. Body with silvery-white pattern of color without spots; hyaline fins. Cheirodon jaguaribensis is a endemic species of the ecoregion Northeast Middle East. Based in the morphological caracteres this species should be classified as genus Hemigrammus instead to Cheirodon.

\section{Serrapinnus heterodon (Eigenmann, 1915)}

Material examined. Table 2.

The genus Serrapinus also belongs to the subfamily Cheirodotinae as the genus Compsura and presents a premaxilla with only one row of teeth, a mandible and a pseudotympanum evident. Serrapinus heterodon have relatively elogated body; head with a mouth terminal, premaxilla and dentary with 1 row of teeth each; Lateral line complete with 33-37 perforated scales. Fins: ii+9-10 dorsal rays; i+9-11 pectoral rays; i+7 pelvic rays; iii+18-20 anal rays. Body silvery-white colored, black spot on the caudal penducle; hyaline fins.

\section{Serrapinnus piaba (Lütken, 1875)}

Material examined. Table 2; Figure 3D.

Relatively elogated body; head with a mouth terminal, premaxilla and dentary with 1 row of teeth each; premaxilla with 12 teeths and mandible with 10-12 teeths; heptacuspid teeth. Lateral line incomplete with 9-12 perforated scales. Fins: i+9 dorsal rays; $i+9-11$ pectoral rays; $i+7$ pelvic rays; $i i+18-20$ anal rays. Body with a silvery-white pattern of color; black spot on the caudal penduncle; hyaline fins.

\section{Erythrinus erythrinus (Bloch \& Schneider, 1801)}

Material examined. Table 2; Figure $3 \mathrm{E}$.

This species of family Erythrinidae is characterized by cylindrical bodies, mouth terminal with conical and/or caniniform teeth, absence of frontanelle and adipose fin. Erythrinus erythrinus have a relatively elogated body; head with a mouth terminal; maxillary bone have only conical teeth. Lateral line complete with 30-33 perforated scales. Fins: $i i+7-8$ dorsal rays; $i+11-12$ pectoral rays; $i+7$ pelvic rays; ii-v+7-9 anal rays. Body yellowish-brown; dark longitudinal band from the operculum until the caudal fin; hyaline fins, the anal fin being orange-red.

\section{Hoplias malabaricus (Bloch, 1794)}

Material examined. Table 2.

Species of family Erythrinidae. Presents elongated body; head with a mouth terminal; maxillary bone with conical and caniniform teeth. Lateral line complete with 41-42 perforated scales. Fins: ii+11-12 dorsal rays; i+11-13 pectoral rays; i+7 pelvic rays; i-ii+8- 
9 anal rays. Body featuring a gray pattern of color; dark spots on the body and fins extent; all fins are hyalines with dark misshapen spots.

\section{Megalechis thoracata (Valenciennes, 1840)}

Material examined. Table 2; Figure $3 \mathrm{H}$.

The only representant of family Callichthyidae in this study, this species presents the body covered by two rows of overlapping bony plates on each side. Megalechis thoracata have a enlogated body; head with a mouth subterminal, with one or two pairs of well-developed barbels. Lateral line with 4-6 pores on superior serie of scutes. Upper row with 25-26 scutes, inferior row with 24 . Fins: I+8 dorsal rays; I+8 or 10 pectoral rays; 6 pelvic rays; 8 anal rays. Presence of adipose fin. Body grayish with rounded spots along all body, including fins.

\section{Hypostomus pusarum (Starks, 1913)}

Material examined. Table 2; Figure 3G.

The only representant of family Loricariidae recorded here, this species have a body covered by more than two longitudinal series of bony plates. Hypostomus pusarum have the anterior portion of the body flattened dorsoventrally; head with a mouth ventrally positioned, lower lip with smalls papillae; long and thin teeth, premaxilla with 21-39 teeth and dentary with 21-42. 25+1 plates on lateral series and 10-11 plate on the base of dorsal fin. Fins: I+7 dorsal rays; I+6 pelvic rays; i+5 anal rays; ii+14 caudal rays; presence of adipose fins. Body brownish with ocellar dark spots along all body, including fins and the ventral portion.

\section{Rhamdia quelen (Quoy \& Gaimard, 1824)}

Material examined. Table 2.

Representant of family Heptapteridae, this species have as an importante character the absence of scales and/or bony plates on the body. Rhamdia quelen have a elongated body; posterior process of supra occipital don't extent until the dorsal fin; relatively smalls eyes; head with a mouth subterminal, upper maxilla longer than the mandible; viliform teeth inserted in dentigerous plates; 3 pairs of barbels. Dorsal fin spines, 7.3 and pectoral, 5.9 in standard length. Fins: I+6 dorsal rays, I+8 pectoral rays; 6 pelvic rays; 12 anal rays. Body have a light grayish color with small dark spots; fins are darkest than trunk.

\section{Gymnotus carapo Linnaeus, 1758}

Material examined. Table 2.

The only representant of family Gymnotidae recorded, this species is characterized by the absence of caudal fin and the a long anal fin. Gymnotus carapo elongated body and laterally compressed; head flattened dorsoventrally; mouth superior with prognathic mandible; premaxilla and dentary with 1 or 2 series of short conical teeth. Lateral line with 75-93 perforated scales. Fins: 15 pectoral rays; 200-240 anal rays. 
Body with a dark brownish color (including anal fin) with lighter diagonal bands on each side.

\section{Poecilia reticulata Peters, 1859}

Material examined. Table 2.

It is an introduced species and represent of family Poeciliidae characterized by small fish that present sexual dimorphism. Poecilia reticulata present a elongated body, head flattened dorsally covered by scales, mouth superior, prognathic mandible; small teeth distributed on the premaxilla and mandible. Longitudinal line with $27^{-}$ 28 scales and a transversal line with 7-8 scales. Fins: $6-8$ dorsal rays; $13-14$ pectoral rays; 6 pelvic rays; 4-10 anal rays. Body yellowish-gray; sexual dimorphism: males have a gonopodium, also presents variable pattern of color and presence of spots.

\section{Poecilia vivipara Bloch \& Schneider, 1801}

Material examined. Table 2.

A native species of family Poeciliidae. Poecilia vivipara have an elonated body; head flattened dorsally covered by scales, mouth superior, prognatic mandible; small teeth distributed on the premaxilla and mandible. Longitudinal line with 27-30 scales and transversal line with 8 scales. Fins: 7-8 dorsal rays; 12-13 pectoral rays; 6 pelvic rays; 7-9 anal rays. Sexual dimorphism: male have a gonopodium. Body yellowish-gray with a black post humeral spot; hyaline fins.

\section{Synbranchus sp.}

Material examined. Table 2.

The only species recorded of the family Synbranchidae characterized by a cylindrical body (serpentine), absence of paired fins (pectoral and pelvic) and the unpaired (dorsal and ventral) are reduced, restricted to the posterior portion of body and confluent to the caudal fin. Synbranchus sp have a serpentineform body; mouth terminal, premaxilla and dentary with small teeht. Only one branchial aperture in the ventral portion; absence of pectoral and pelvic fins. Body brownish with the dorso darkest than ventral portion presenting numerous small black spots.

\section{Cichlasoma orientale Kullander, 1983}

Material examined. Table 2.

Family Cichlidae characterized by the presence of lateral line divided in two branches - an upper one arranged more dorsally and another one lower ventrally arranged. Cichlasoma orientale have an ovate and deep body; mouth terminal, tiny and conical teeth. Upper lateral line with 16-18 perforated scales and inferior line with 8-11 scales. Fins: XIV-XVI+10-11 dorsal rays; 13-14 pectoral rays; I+5 pelvic rays; II-IV+7-9 anal rays; 16 caudal rays. Color predominantly dark brownish with two black rounded spots - one on the flank and another on the caudal peduncle. 


\section{Crenicichla menezesi Ploeg, 1991}

Material examined. Table 2; Figure $3 \mathrm{~F}$.

Species of the family Cichlidae. Crenicichla menezesi have elongated body; mouth terminal; several series of short teeth on the premaxilla and dentary. Upper lateral line with 22-24 perforated scales and lower line with 11-12. Fins: XVIII-XIX+11-13 dorsal rays; $14-16$ pectoral rays; I+5 pelvic rays; III+8-9 anal rays. Color predominantly yellowish-gray with two ocellar dark spot - one humeral and another one on the bse of caudal fin. Often have an inconspicuous dark band along the middle lateral region of the body (from the head to the caudal fin).

\section{REFERENCES}

Albert JS, Petry P, Reis RE. 2011. Major biogeographic and phylogenetic patterns. In: JS Albert and RE Reis (eds.), Historical Biogeography of Neotropical Freshwater Fishes. Berkeley University of California Press, 21-58.

Bichuette ME, Trajano E. 2003. Epigean and subterranean ichtyofauna from the São Domingos karst area, Upper Tocantins River basin, Brazil. Journal Fish Biology 63:1100-1121. https://DOI: 10.1046/j.1095-8649.2003.00227.X

Böhlke J, Weitzman SH, Menezes NA. 1978. Estado atual da Sistemática de peixes de água doce da América do Sul. Acta Amazônica 8: 657-677.

Britski HA, Silimon KZS, Lopes BS. 1999. Peixes do Pantanal: manual de identificação. Embrapa, Brasília, 184 pp.

Buckup PA, Menezes NA, Ghazzi MS. 2007. Catálogo das espécies de peixes de água doce do Brasil. Museu Nacional, Rio de Janeiro, 195 pp.

Conservation International, Fundação Biodiversitas, Sociedade Nordestina de Ecologia, Ministério do Meio Ambiente, dos Recursos Hídricos e da Amazônia Legal. 1993. Mapa síntese das prioridades para conservação da biodiversidade da Mata Atlântica do Nordeste. In: Áreas Prioritárias para Conservação da Biodiversidade da Mata Atlântica do Nordeste, Itamaracá.

Dias TS, Fialho CB. 2009. Biologia alimentar de quatro espécies simpátricas de Cheirodontinae (Characiformes, Characidae) do rio Ceará Mirim, Rio Grande do Norte. Iheringia, Série Zoologia 99 (3): 242-248. http://dx.doi.org/10.159o/Soo7347212009000300003 . 
FUNDEP-UFMG. 2006. A ictiofauna do Reservatório de Três Marias, Rio São Francisco, Minas Gerais. Estudo técnico-científico visando a delimitação de Parques Aquícolas nos lagos das Usinas Hidroelétricas de Furnas e Três Marias-MG. Convênio 8713, 66 pp.

Gonçalves CS, Braga MS. 2013. Checklist of freshwater ichthyofauna from coastal streams of Juréia-Itatins reserve, southeastern Brazil. CheckList 9 (2): 175-185. http:// dx.doi.org/10.1556o/9.2.175

Graça WJ, Pavanelli CS. 2007. Peixes da Planície de Inundação do Alto Rio Paraná e Áreas Adjacentes. Eduem, Maringá, 241 pp.

Granado-Lorencio C, Lobo-Cerviá J, Araujo-Lima CRM. 2007. Floodplain lake fish assemblages in the Amazon River: directions in conservation biology. Biodiversidade Conservação 16: 679-692.

Kavalco KF, Pazza R. 2007. Aspectos biogeográficos de componentes da ictiofauna da América Central. ConScientiae Saúde 6 (1): 147-153.

Kullander SO. 2003. Family Cichlidae (Cichlids). In: RE Reis, SO Kullander, CJ Ferraris, Jr. (eds.), Checklist of the Freshwater Fishes of South and Central America. EDIPUCRS, Porto Alegre, 605-654.

Instituto Brasileiro de Geografia e Estatística (IBGE). 1992. Manual técnico da vegetação brasileira. IBGE, Rio de Janeiro, 92 pp.

IUCN - IUCN Red List of Threatened Species. 2016. http://www.iucnredlist.org/. Accessed on: 02-06-20167.

Langeani F, Buckup PA, Malabarba LR, Py-Daniel LHR, Lucena CAS, Rosa RS, Zuanon JAS, Lucena ZMS, Britto MR, Oyakawa OT, Gomes-Filho G. 2009. Peixes de Água Doce. In: RM Rocha, WAP Boeger (orgs.), Estado da arte e perspectivas para a zoologia no Brasil. Ed. UFPR, Curitiba, 211-230.

Leal ME, Bremm CQ, Schulz UH. 2009. Lista da Ictiocenose da Bacia do Rio dos Sinos, Sul do Brasil. Boletim Instituto de Pesca 35 (2): 307-317.

Lourenço LS, Fernandes IM, Suarés YR. 2012. Spatial and temporal variation in population structure of Hemigrammus marginatus (Characiformes: Characidae) in streams of the Ivinhema River Basin, Brazil. Zoologia 29 (4): 300-307. http://dx.doi. org/10.1590/S1984-46702012000400003 
Lowe-Mcconnell RH. 1999 Estudos ecológicos de comunidades de peixes tropicais. Edusp, São Paulo, 536 pp.

Medeiros ESF, Ramos RTC, Ramos TPA, Silva MJ. 2006 Spatial variation in reservoir fish assemblages along semi-arid intermittentriver, Curimataú River, northeastern Brazil. Revista de Biologia e Ciencias da Terra 1: 29-39.

Melo MRS, Espíndola VC. 2016. Description of a new species of Characidium Reinhardt, 1867 (Characiformes: Crenuchidae) from the Chapada Diamantina, Bahia, and redescription of Characidium bimaculatum Fowler, 1941. Zootaxa 4196 (4): 552-568.

http://doi: 10.11646/zootaxa.4196.4.5.

Melo CE, Lima JD, Melo TL, Pinto-Silva V. 2005. Peixes do Rio das Mortes identificação e ecologia das espécies mais comuns. Unemat, Cuiabá, 147 pp.

Menezes NA. 1996. Methods for assessing freshwater fish diversity. In: CEM Bicudo, NA Menezes (eds.), Biodiversity in Brazil. CNPq, São Paulo, 289-295.

Menezes NA, Weitzman SH, Oyakawa OT, Lima FCT, Castro RMC, Weitzman MJ. 2007. Peixes deágua doce da Mata Atlântica: lista preliminar das espécies e comentários sobre conservação de peixes de água doce neotropicais. MZUSP, São Paulo, 407 pp.

Ministério do Meio Ambiente. 2014. Portaria n 445, de 17 de Dezembro de 2014. Lista Nacional Oficial de Espécies da Fauna Ameaçada de Extinção: Peixes e Invertebrados Aquáticos. Diário Oficial da União, Brasília, 126-13o.

Myers N, Mittermeier RA, Mittermeier CG, Fonseca GAB, Kent J. 20oo. Biodiversity hotspots for conservation priorities. Nature 403: 853-858.

Nelson JS. 2006. Fishes of the world. New York, John Wiley. 6oipp.

Oyakawa OT. 2003. Family Erythrinidae. In: RE Reis; SO Kullander; CJ Ferraris, Jr. (eds.), Checklist of the Freshwater Fishes of South and Central America. EDIPUCRS, Porto Alegre, 605-654.

Paiva MP, Campos E. 1995. Fauna do Nordeste do Brasil. Conhecimento científico e popular. Banco do Nordeste do Brasil, Fortaleza.

Pereira MDB, Souza-FilhoJF, Moura MO. 2012. Análise da pluviosidade na Microrregião de Sapé, Paraíba e sua relação com a produção da cana-de-açúcar. Revista Geonorte 2 (5): 910-921. 
Pompeu PS, Godinho HP. 2003. Ictiofauna de três lagoas marginais do médio São Francisco. In: HP Godinho, AL Godinho (orgs.), Água, peixes e pescadores do São Francisco das Minas Gerais. PUCMinas, Belo Horizonte, 67-181.

Ramos RTC, Ramos TPA, Rosa RS, Beltrão GBM, Groth F. 2005. Diversidade de Peixes (Ictiofauna) da bacia do rio Curimataú, Paraíba. In: FS Araujo, MJN Rodal, MRV Barbosa (eds.), Análise das variações da biodiversidade do bioma caatinga: suporte das estratégias regionais de conservação. Ministério do Meio Ambiente, Brasília, 291318.

Ramos TPA. 2012. Ictiofauna de Água Doce da Bacia do Rio Parnaíba. João Pessoa, Paraíba. Ph.D. Universidade Federal da Paraíba, 215 pp.

Ramos TPA, Ramos RTC, Ramos SAQA. 2014. Ichthyofauna of the Parnaíba river Basin, Northeastern, Brazil. Biota Neotropica 14 (1): 1-8. https://doi.org/10.159o/ s1676-06020140039

Reis RE, Kullander SO, Ferraris CJ. 2003. Check List of the Freshwater Fishes of South and Central America. EDIPUCRS, Porto Alegre, 729 pp.

Rosa RS, Groth F. 2004. Ictiofauna dos ecossistemas de Brejos de Altitude de Pernambuco e Paraíba. In: KC Porto, JJP Cabral, M Tabarelli (eds.), Brejos de Altitude em Pernambuco e Paraíba, História Natural, Ecologia e Conservação. Ministério do Meio Ambiente (série Biodiversidade, 9), Brasília, 201-210.

Santos AJ. 2006. Estimativas de riqueza em espécies. In: L Cullen, C Padua-Valladares, R Rudran (eds.), Métodos de estudos em biologia da conservação da vida silvestre. ª̊ed. Ed. Universidade Federal do Paraná, Curitiba, 19-42.

Sarmento-Soares LM, Martins-Pinheiro RF. 2009. A fauna de peixes na bacia do Rio do Frade e microbacias vizinhas, extremo Sul da Bahia. Boletim Museu Biologia Mello Leitão 26: 25-46.

Silvestre LC, Xavier SRS. 2013. Samambaias em fragmento de Mata Atlântica, Sapé, Paraíba, Brasil. Boletim do Museu Paraense Emílio Goeldi. Ciências Naturais 8 (3): 431-447. https://DOI10.13140/2.1.2476.6084

Sparre P, Venema SC. 1997. Introdução à avaliação de mananciais de peixes tropicais. Parte 1: Manual. Roma, FAO, 404 pp.

Vieira F, Santos GB, Alve CBM. 2005. A ictiofauna do Parque Nacional da Serra do Cipó (Minas Gerais, Brasil) e áreas adjacentes. Lundiana (supplement): Instituto de Ciências Biológicas - UFMG, 77-87. 